\title{
Discussion on Teaching Mode of "Micro" Course for Military Undergraduates' Graduation Internship Facing Actual Combat
}

\author{
Liu Longbin ${ }^{a}$, Hu Fan $^{\mathrm{b}}$, Jiang Zhenyu ${ }^{\mathrm{c}, *}$, Gong Mingshu ${ }^{\mathrm{d}}$ \\ College of Aeronautical Science and Engineering, National University of Defense Technology, Deya Road, \\ Changsha, 410073, China \\ a longbuaa@163.com, ${ }^{b}$ hufan_nudt@126.com, ${ }^{c}$ jjiangzhenyu00@yeah.net, ${ }^{\mathrm{d}}$ gongmingshu001@163.com \\ *corresponding author
}

Keywords: Graduation internship; Micro-course; Teaching reform; Actual combat; Practice base.

\begin{abstract}
For the importance of graduating internships for military undergraduates in cultivating high-quality personnel and the urgent need for practical training in military personnel training, based on the practical problems existing in the incessant new types of weapons equipment and undergraduate internships in recent years, A new model of undergraduate graduation practice using "micro" courses to assist teaching is proposed, which includes a new teaching model combining "micro" class organization and "micro" point teaching with on-site visits to practice bases. This model could help undergraduates to preview the content of internships in advance, and to conduct targeted public inspections of actual combat weapons and on-site questions, which will enable undergraduates to understand the basic essentials for actual combat during the limited internship time and improve the internship of military undergraduate students, meanwhile, the interest and enthusiasm of self-study for the internship content of military undergraduate teams could be improved, which provided the important reference for improving the quality and efficiency of graduation practice of facing military operations for military academies undergraduates.
\end{abstract}

\section{Instructions}

According to the requirements of the school's training program, undergraduates in military academies must conduct professional internships before graduation. Undergraduate graduation internship is an important undergraduate teaching part for cultivating high-quality military personnel. In order to promote students to better summarize and experience the school learning theoretical knowledge, undergraduate engineering practice professional internships are generally arranged outside the school practice base or undergraduate professional counterparts [1, 2]. The undergraduate graduation practice is also the most crucial link for undergraduates to apply their combined professional knowledge and practice before graduating, and to develop analytical problems and problem solving skills to enhance their innovate practice ability [3, 4]. However, for undergraduates in military universities, the internship plan and funding guarantees could be determined in advance, but with the continuous upgrading of the internship base's weapons and equipment in recent years, and the requirement of military academies train students to face actual combat, the higher requirements are placed for the teaching content of undergraduate graduation practice [5-7]. Meanwhile, due to the intense training tasks of undergraduates, the time for graduation practice is very short $[8,9]$. Therefore, the problem is imminent how to improve the efficiency and quality of students' graduation practice, which is worth further research to let students obtain systematic and effective workout.

Based on the "Internet+" teaching reform background, this paper proposes a new teaching model combining the "micro" class organization and "micro" class key teaching with practice base visits in accordance with the training requirements of military students for practical undergraduate graduation practice, which could help undergraduates to understand the plan of internship organization in advance, prepare for the content of internships, review the actual weapons and equipment of interest, stimulate the autonomy, interest, and enthusiasm of students, which is 
important for improving the quality and efficiency of graduation practice for facing military academies.

\section{Micro course internship organization plan}

At present, most of the undergraduate internships still use the centralized practice mode, which facilitates centralized organization, supervision, and management. But it requires a large number of teachers to communicate in the early stages to formulate detailed internship plans. Considering the cumbersomeness and timeliness of the various contents of the internship plan, in order to allow students to understand the contents of the internship plan on time, it is necessary to inform all students participating in the internship on time. However, due to restrictions on school curriculum and time, students should start before graduation practice. It is impossible to inform students the trivial organizational planning information at any time, which could use the micro-teaching method to solve the problem of informing the intern organization plan information in real time. and the content of the internship program organization is very tedious shown in Fig.1.



Figure 1 Undergraduate graduation internship organization coordination

(1) Coordinating with internship base: There are not many professional counterparts, in-depth training contents and lacking of practical links in the graduates' internships for national defense specialty of military academies [3-5]. Team teachers need to coordinate with their professional counterparts in advance, which is also possible to assign a unit or enterprise signed an internship cooperation agreement according to the principle of students' professional relevance. The professional instructors are responsible for coordinating the day-to-day management matters contents of the professional internship. The content of the internship determined by consultation should meet the requirements of the student's internship training program and the confidentiality, safety production and process flow. These contents are made into micro lesson texts.

(2) The internship plan preparation: according to the internship practice outline requirements, all aspects of the graduation practice should be planned and standardized. It is necessary to meet the internship requirements and conditions of the students, which also should consider the specific arrangement every day as detailed as possible. So it is possible to formulate and produce micro-course segments each an hour, including the guidance teacher, factory address, route and so on. The detailed internship program needs to be worked out by the internship units and the school's professional guidance teachers. If necessary, the school's professional tutors could make a full investigation before starting the internship, and then combine the internship practice requirements to determine the daily internship purposes, tasks, contents, practice methods, schedules, disciplinary requirements, assessment and performance evaluation and attention matters. Such micro-course content could directly enable students to know the internship content and schedule in advance.

(3) Internship practice mobilization: Student internship practice mobilization activities could be carried out and help students attach practice importance and increase the enthusiasm to actively participate in internships. Moreover, it could implement professional instructors' responsibilities. For the example of missile engineering majors, a temporary party branch had been set up at the mobilization meeting with excellent students taking the lead to carry out internship discussions. 
Disagreement events in organization management could be resolved in a democratic and centralized resolution. If there are questions about the internship content, we could promptly put questions to the professional instructor, which makes it not only improve students' enthusiasm for participating in internships, but also enhance the ability of internship practices to solve problems on the spot.

The practice mobilization and the whole process practice put forward higher requirements for the professional guidance teachers. In addition, teachers should have rich experience in engineering practice to improve the internship quality and effectiveness. It is recommended to adopt the " $1+1+1$ " model of the instructor team, that is, one professional instructor, one professional instructor, and one team cadre. The old teacher has more professional experience and prestige in organizational management, and the new teacher mainly learns from the old teacher and does some trivial and auxiliary work [1, 9-11]. This type professional internship instructor team is conducive to the mutual complementation internship organization throughout the entire process.

(4) Round-trip route planning: coordinating the school with the internship base, the planned internship program basically determines the internship practice roundtrip route. In the case of internship units have one more internship sites, schools need to make micro lesson about the practice of scheduling and 'production in advance, and to tell students the travel service, tickets, bus time points, setting position, board and lodging place. In addition, the school also needs to prepare contingency plans in advance to ensure students' absolute life and property safety.

(5) Attention matters: because the military students are all under the unified command and collective action of the team cadres in the school, the undergraduate graduation internship is the first time to leave the troops to the social unit or enterprise. Professional guidance teachers need to inform the various points that may affect the internship activities in advance. Such as the national defense security, business secrets of enterprises, operational safety, practice codes, safety of transportation, requirements of accommodation, materials and so on.

This micro-class graduation internship organization model effectively solves the problem of students' temporary reception of internship organization information and internship organization's arrangement, which not only improve the efficiency and quality of military school undergraduate graduation practice organization, but also has realized the student understanding practice organization form, content and practice other matters before heading to practice base in advance.

\section{Micro-course teaching}

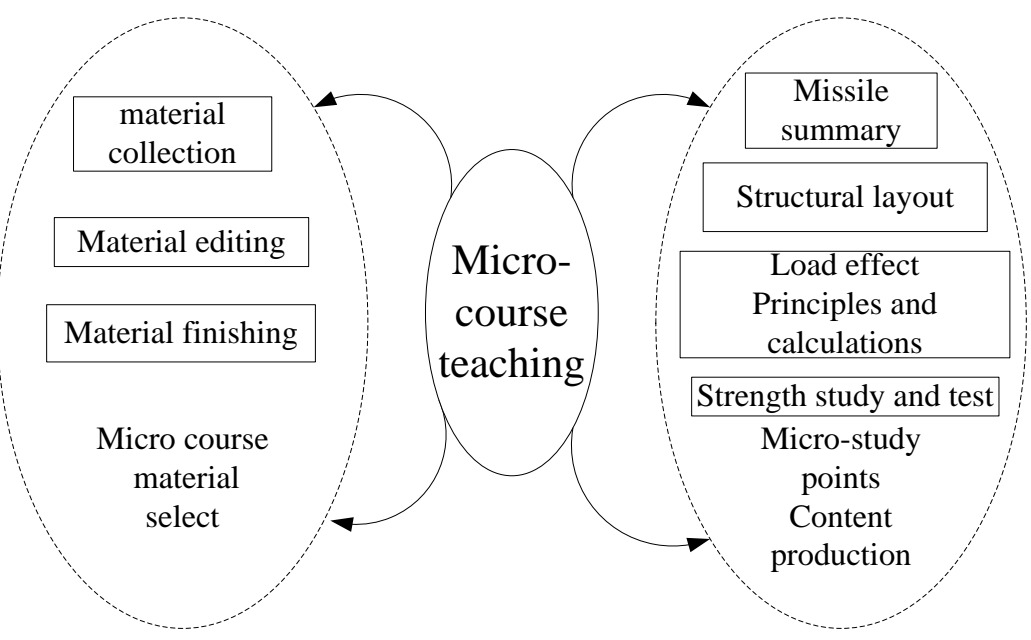

Figure 2 This is a micro lesson teaching frame

Due to the short time of students' internships, students' graduation internships may not be arranged exactly among the internship unit conducting the new combat weapons and equipment experiment. However, school authority could contact the actual practice subject content with the internship unit. The team-training teacher creates micro-class texts, pictures, or video clips with the practice base based on the content points of the internship subjects that could not be on-site to visit the internship. And students could combine the static weapons equipment learned on-site practice 
base to learn the actual working principles, methods of operation, attack procedures, navigation guidance methods, etc. Meanwhile, it is convenient for students to carry out independent data access and in-depth study according to the content points suggested by the micro-curriculum, and to carry out targeted explorations of students' individualization issues to stimulate student interest.

\subsection{Micro-teaching material selection}

The internship original material is the key to the production of micro-curriculum teaching content, which could be provided by the internship base or obtained by the instructing teacher from the internship base in advance. A separate micro-education subject must have complete material content. The key points should be highlighted, and the logical relationship between the structural modules should be reasonable. They should be displayed together with text, pictures, audio to provide rich and vivid teaching content for the micro-curriculum, which help improve the students' initiative and interest in watching and learning the teaching content of micro lessons in advance. Taking the undergraduate graduation practice of missile engineering majors of our school as an example, detailed introduction and explanation of one missile micro-course is performed as bellow.

(1) Basic material collection: The basic material of a certain type missile includes the appearance and structural pictures of the static and all-position on site, such as the hood, the middle cabin segment, the tail end, the engine, the missile wing, the rudder, the internal cabin structure, and the electrical circuit layout, navigation and guidance control components and so on. It could also include dynamic pictures and video data during missile transition, transportation and launch. The basic material is closely related to the type of missile that undergraduates shall study at the practice base, which could directly and accurately reflect the missile type with the basic structural composition, flight process control, basic operations principles for students to practice.

(2) Material Editing: The material information collected will be further selected. For the pictures and video materials involving the dynamic flight principle and the combat control process, the editorial software will be used to add related introductory words and key content identifiers for the students to learn, so students could be able to grasp the key points and have targeted learning. For some subjects that students could not perform on spot operations, the commentary videos could be recorded by the professional engineering staff of the practice base, and the editing method could be used to assemble the commentary micro-teaching text or pictures into separate modules to provide the basic material support for the follow-up micro-study key videos, which could let the student feel immersive missile and the basic process operation steps.

(3) Material Finishing: For the dynamic process of multi-module demonstration or the missile working principle material without on-site testing, the introductory animation can be processed according to the needs, and the animation effect can be used to increase the visibility of the micro-course material, which is helpful for the understanding of the subject internship content [13]. Because it is difficult to achieve the effects of dynamic presentations in close proximity to text or pictures, creating animations can provide supplementary materials for on-site shooting materials to facilitate students' detailed understanding of missile structure layout and working principles.

\subsection{Micro-course main content production}

Based on the preliminary selection of micro-curricular internship materials and the needs of graduate-training contents for practical undergraduates, the key points of micro-education for internships were produced taking a certain missile practice as an example, and the internship point production micro-course content includes structural comprehensive layout form, load principle and calculation analysis, strength research and experiment and so on. The main points of the micro-curricular content are short, precise, focused, clear logic, text color, format, font clear, easy for students to learn in advance. The micro lessons content could briefly introduce the composition and function of each part, and as the content of the micro-learning course, the interested students could further understand and learn, and it could expand the range of knowledge that the students' internships focus on. It is a good preparation for students to learn and consult materials in advance, and prepare questions and studies on the spot. 


\subsection{1 micro-course production of integrated structure layout}

Since the internship base could only provide students with internship visits for a limited number of missiles, students could not fully understand the comprehensive layout of the missile structure on-site visits, and are also not conducive to intuitive teaching on the spot. Thus making the missile comprehensive layout class material structure could help students understand the characteristics of the missile comprehensive layout design of complex structure in advance (design constraints, content more, coordination, preparation [12]), task requirements, design principles, structural processes, and others. Combining the live pictures and animation materials shot at the practice base could make a dynamic micro lesson video, and it is possible to facilitate the students to understand the structural scheme and dynamic connection mode of each compartment of the missile within a short time as well as the cabin segment and the layout of the program and principles.

In combination with the knowledge points of each module of the missile structure that students could study in depth, according to the teaching content of the micro-class, students could further choose to learn the structural forms and characteristics of the main components of the missile structure and so on, which are convenient for students to learn on their own corresponding to the practice base physical model and could inspire students' active thinking and targeted learning. And it could be combined with the theoretical book knowledge learned in the school classroom and the missile entity model in the practice base to improve students' ability to understand the integrated layout knowledge of the missile structure, which also improves the quality and efficiency of undergraduate graduation practice and breaks the traditional teaching model of "walking horses".

\subsubsection{Principles of Load Action and Calculation Analysis}

Due to the limited field and study time of the practice base, it is impossible to complete the analysis and calculation of the load of a certain type of missile in a short time. Therefore, the missile load data provided in the early stage of the practice base could be combined to lead the teacher to make the micro course analysis of missile load analysis and calculation. Teaching content includes the missile force and moment characteristics on the flight trajectory, load factor, calculation of internal forces during active flight, and calculation of the load of the missile erected on the launch pad, load calculation when using ground transportation, load destruction and strength reserve Ability calculations and more. Through the micro-video content of the modules, students learn ahead about the load analysis and calculation process of a new type missile at the practice base, so that they could easily understand the concluding knowledge, which also reinforce the basic theoretical knowledge that students learn in school.

\subsubsection{Intensity research and experiment micro-course production}

Considering short time and the safety of students' internships, it is impossible for a general internship base to arrange students to enter the missile test area, or to visit the practice base for study when the base conducts a missile test. Therefore, for the experimental type of student internship, the team teacher and the practice base could communicate and coordinate in advance, and the missile strength research and experiment content module is made into a micro-class model, which helps students to become familiar with the basic content and main operations of the missile strength study in advance, which also includes the missile structure's static strength analysis, dynamic strength research, thermal strength and other natural and mechanical environment strength stiffness analysis and calculation process and so on. Therefore, the long-time demonstration process could be completed with the new teaching mode of miciro-video internship in a short time, which could help students to become familiar with the basic flow of missile strength analysis and calculation in a short period of time, and avoids the students only knowing the macro characteristics of the missile's flight intensity and improves the internship efficiency and quality.

\section{Conclusion}

Based on the 'Internet +'micro-class mode of undergraduate internship teaching mode, it helps 
students to advance understanding of military practice organization plan, and preview the content of the internship subject in advance. For professional issues of interest, students could refer to the information on actual combat weapons and equipment, which motivate students' autonomy, interest and enthusiasm in participating graduation practice. Moreover, through the new micro-curriculum mode, undergraduates understand the fundamental essentials of actual practice subjects in a limited time, which is conducive to students' comprehensive synthesis and comparison of theoretical knowledge and internships learned in schools. it has important reference significance for improving the quality and efficiency of the graduation practice for facing actual combat.

\section{Acknowledgements}

The research is funded by the research project of the National University of Defense Technology (NUDT) (No. ZK16-03-33) and the Natural Science Foundation of Hunan Province (Grant No.2018JJ3591), as well as Education Teaching Research Project of NUDT (U2016001).

\section{References}

[1] Chen, Z. C., Yao, L., Li, W. (2012) Problems and Considerations of undergraduate graduation practice in military colleges. China Electric Power Education, 23, 98-99. (in Chinese)

[2] Li, G. f., Li, Y. l., Zhang, Z. G, et al. (2007) On the Teaching and reform of college graduation practice in colleges. Journal of Changsha University, 21, 90-93. (in Chinese)

[3] Li, X. K., Wan, J., Gao, M. S. (2015) Research on the construction and practice of undergraduate graduation practice in colleges. Heilongjiang Higher Education Research, 252, 97-100. (in Chinese)

[4] Zhong, C. T., Zong, Y. R., Li, J., (2011) Analysis of difficulties and countermeasures to realize the integration of military and civilian in scientific research activities in colleges. Scientifical and Technological Progress and Countermeasures, 28, 144-149. (in Chinese)

[5] Xu, H. P. (2008) School-enterprise cooperation in the exploration of undergraduate graduation practice. Scientifical Square, 9, 229-230. (in Chinese)

[6] Xie, J. X., Liu, H. S., Li, Z, et al. (2017) Research and Practice of Graduation Practice Course Reform in Electronics Majors. Educational Modernization, 4, 97-98. (in Chinese)

[7] Sun, Y. J., Chen, H., Hao, Z. Y. et al. (2015) A brief analysis of the present situation of undergraduate graduation practice and the ways to improve. Practice Training, 10, 167-169. (in Chinese)

[8] Lou, M. (2016) Establishment and practice of the evaluation system for graduation practice of Engineering Majors Based on Process Method. University Education, 9, 122-124. (in Chinese)

[9] Chen, W. B., Shen, L., Ma, W. X. et al. (2009) The exploration of cooperation between colleges and enterprises in higher education. Science and Technology Innovation Review, 31, 235-238. (in Chinese)

[10] Zhang, H. (2012) Grasping the graduation practice to improve the comprehensive quality of undergraduates. Heilongjiang Education (Higher Education Research and Evaluation), 2, 85-86. (in Chinese)

[11] Lou, M. (2016) Establishment and Practice of a Graduation Practice Examination System for Engineering Majors Based on Process Method. University Education, 9, 122-124. (in Chinese)

[12] Wei, X. G., Fu, S. G., Zhang, K. Y, et al. (2016) Research and Practice of Micro-class making based on the reform metalworking practice teaching. Laboratory Research and Exploration, 35, 222-226. (in Chinese) 